\title{
USING HIGH IMPACT PRACTICES TO MEET EMPLOYER 'SOFT SKILL' EXPECTATIONS IN COMPUTER INFORMATION SYSTEMS EDUCATION
}

\author{
Bruce M. Saulnier, Quinnipiac University, bruce.saulnier@quinnipiac.edu
}

\begin{abstract}
The modern workplace is discussed and implications of the workplace for the Computer Information Systems (CIS) curriculum are presented. Employer expectations for baccalaureate CIS graduates are presented based on current research studies. Given these expectations, it is proposed that the American Association of Colleges \&Universities' (AAC\&U) LEAP initiative may be of assistance in providing graduates meeting the employer expectations. LEAP's Essential Learning Outcomes (ELOS) and High Impact Practices (HIPS) are presented. Examples of using HIPs across the CIS curriculum are provided, and it is posited that the use of HIPs in the CIS curriculum has assisted in providing CIS graduates meeting the employer expectations. It is concluded that it is just as important to focus on pedagogy (how we teach) as it is to define our curricular content (what we teach) in meeting employer demands for successful $21^{\text {st }}$ century CIS graduates.
\end{abstract}

Keywords: Employer Expectations, Soft Skills, CIS Pedagogy, LEAP Initiative, Essential Learning Outcomes, High Impact Practices

\section{THE $21^{\text {ST }}$ CENTURY WORKPLACE}

"A good hockey player plays where the puck is. A great hockey player plays where the puck is going to be."

$$
\text { - Wayne Gretzky }
$$

Peter Vaill (1989) introduced the term "permanent white water" to describe the turbulent environment in which we all live and work. Since the introduction of that phrase, the speed with which change is occurring has accelerated, and Vaill's term "permanent white water" has proven to be prophetic. All college students, regardless of their field of study, need to be prepared to contribute in a world marked by open or unscripted problems - problems where the right answer is far from certain and where solutions are therefore necessarily created under conditions of uncertainty.

Today we are educating our students for jobs and career paths that do not yet exist, using technologies that have yet to be invented, to solve problems that we don't even know are problems yet. These are the kinds of problems we face in today's economy, which is fueled by innovation and ongoing, turbulent change. As Schneider (2015) so aptly puts it, "These are also ... the kinds of problems we face both in the global community and in our own diverse and deeply divided democracy. Indeed, our graduates are entering a world of extraordinary complexity and uncertainty. The solutions they create will hold lasting consequence for our shared future."

Hart Research Associates (2013) conducted an online survey among 318 employers whose organizations have at least 25 employees. Responders were executives at private sector and nonprofit organizations, including owners, CEOs, presidents, C-suite level executives, and vice presidents. A key finding was that $95 \%$ of those surveyed said they gave hiring preference to college graduates with skills that will enable them to contribute to innovation in the workplace. Nearly all of those surveyed (93\%) agreed that "a candidate's demonstrated capacity to think critically, communicate clearly, and solve complex problems is more important than their undergraduate major." More than $90 \%$ of those surveyed said that it is important that those they hire demonstrate ethical judgement and integrity, intercultural skills, and the capacity for continued learning. More than $75 \%$ said they wanted colleges to place more emphasis on helping students to develop five key learning outcomes, including critical thinking, complex problem solving, written communication, oral communication, and applying knowledge in real-world settings. 


\section{THE COMPUTER INFORMATION SYSTEMS CURRICULUM DILEMNA} "The greatest danger in times of turbulence is not the turbulence: it is to act with yesterday's logic."
- Peter Drucker

\section{CIS Employer Expectations}

Studies of employer expectations have been an ongoing concern to undergraduate CIS educators for at least the past decade. Cappel (2002), Janicki, Kline, Gowan \& Konopaske (2004), and Fang, Lee \& Koh (2005) conducted studies based on employer and recruiter interviews, studies which focused primarily on hard skills which served to direct curricular modification. Similar studies were conducted by Plice \& Reinig (2007) and McMurtry, Downey, Zeltman \& Friedman (2008). A longitudinal study summarizing most of the prior research on hard skills was conducted by Aasheim. Shropshire, Li \& Kadler (2012).

An interesting study focusing primarily on an alumni assessment of MIS related job skills and the skill gap of graduates was conducted by Wilkerson (2012). During the study Wilkerson found that while hard skills were indeed of ongoing importance, the greatest skill gaps mentioned by alumni of the program were in the "soft skill" areas. Heckman \& Kautz (2012) also found that lack of graduates' soft skills was the greatest gap in employer expectations.

As technology continues to evolve, CIS programs in colleges and universities find themselves continuously striving to keep up with the latest technology advances. However, based on the findings of the previous studies, perhaps what really needs to be happening regarding curricular reform is to focus on which of the non-technical skills are being addressed and how frequently they are being reinforced throughout the curriculum. Bailey (2014) conducted a study focused solely on the non-technical skills needed for IT professionals. She found that some of the highest ranking nontechnical skills included problems solving, team work, and the ability to adapt to new technologies and languages that were continuously being introduced into the workplace. Perhaps these are areas in which both technical skills and non-technical skills could be combined.

As part of an ongoing effort to improve our CIS curriculum by better aligning it with employer needs, we need to better understand the desired skills for entry-level systems analysts. Lang, Jones \& Leonard (2015) conducted a longitudinal survey/study to determine current employer expectations for entry-level IT professionals, and concluded that personal and interpersonal skills remain at the top of the employer wish-list. In particular, problem solving, team work, and the ability to adapt to new/changing technologies were considered by employers to be critical $21^{\text {st }}$ century skills. However, they also found that technical skills are still considered very important.

Our direct contact with employers who hire our students both as interns and upon graduation indicates that they also want soft skills in addition to the hard skills particular to their organizations. In most cases the employers of our graduates have indicated that with good soft skills and a willingness and capability to learn, they can then either teach the new hires the hard skills particular to their company, or the new employees can be expected to teach themselves the technology skills particular to their employer.

\section{The Challenge of the CIS Curriculum}

Vaill (1996) argued that as a one response to the problem of how best to navigate the world of permanent white water, institutions of higher education must teach managers how to integrate the discipline of learning into their very being. As strong and valid as Vaill's idea is, the strategic idea at the heart of this paper extends beyond that of Vaill. Indeed, this paper posits that future proposals for driving any changes in the CIS curriculum should be based on the intentional integration of the liberal arts skill sets within the required CIS courses. That is, it is not sufficient to simply require that CIS students also study the liberal arts, but liberal arts concepts and perspectives need to be professionalized and taught in the context of real-world CIS problems. Further, that CIS curriculum development efforts need to be enriched, nuanced, and in fact critiqued through the lenses of the ideas and perspectives of the liberal arts. This requires intentionality and effort from all department faculty who are both engaged in and involved with undergraduate education. 
The key challenge in formulating our approach to undergraduate CIS education is not just in defining which traditional areas of the curriculum are most appropriate for educating our $21^{\text {st }}$ century students, for just as in the past those details will evolve over time as new technologies emerge and find their place in the work place and society. The major challenge is to define the essential attitudes and abilities necessary for our students to function effectively and efficiently in the $21^{\text {st }}$ century, both professionally and personally. Fortunately, a national conversation addressing this issue, by making the Liberal Arts more applicable and integral to career education, has been taking place for the last decade.

\section{LEAP, ESSENTIAL LEARNING OUTCOMES AND HIGH IMPACT PRACTICES}

"The biggest and most long-lasting reform of undergraduate education will come when individual faculty or small groups of instructors adopt the view of themselves as reformers within their immediate sphere of influence, the classes they teach every day."

$$
\text { - K. Patricia Cross }
$$

Liberal Education and America's Promise (LEAP) is an program/initiation of the Association of American Colleges and Universities (AAC\&U), a national association whose focus is on improving undergraduate education and advancing the contributions that can be made by effective liberal education. LEAP (2005) “... champions the importance of a twenty-first-century liberal education - for individual students and for a nation dependent on economic creativity and democratic vitality." By employing the guidance provided by LEAP, a great many colleges and universities across the nation are making potentially far-reaching educational changes to help all of their students, independent of their chosen field of study, acquire the broad knowledge, higher order thinking capacities, and real world experience needed to thrive in both the current economy and in our globally engaged democracy.

\section{The Essential Learning Outcomes (ELOs)}

LEAP's four (4) Essential Learning Outcomes (ELOs), are designed to be guiding visions and national benchmarks for college learning and liberal education in the $21^{\text {st }}$ century. By the time of graduation, LEAP seeks students to have

- "Knowledge of Human Cultures and the Physical and Natural World - through study in the sciences and mathematics, the social sciences, humanities, histories, languages, and the arts focused by engagement with "big questions", both contemporary and enduring;

- Intellectual and Practical Skills - including inquiry and analysis, critical and creative thinking, written and oral communication, qualitative literacy and information literacy, and teamwork and problem solving, practiced extensively across the curriculum, in the context of more challenging problems projects, and performance standards;

- Personal and Social Responsibility -- including civic knowledge and engagement (both local and global), intercultural knowledge and competence, ethical reasoning and action, and foundations and skills for lifelong learning, anchored through active involvement with diverse communities and real-world challenges.

- Integrative and Applied Learning - including synthesis and advanced accomplishment across general and specialized studies, demonstrated through the application of knowledge, skills, and responsibilities to new settings and complex problems."

But the obvious and driving questions are: Just how do students attain such a noble yet essential set of learning outcomes? How can we design our curricula and what pedagogical practices can we employ to move students in the direction of such aspirational objectives?

\section{High Impact Practices (HIPs)}

Kuh (2008) introduced the concept of high impact educational practices; research-based teaching and learning practices that have been widely tested and have been shown to be beneficial for all college students, especially those from groups that historically have been underserved by higher education. These practices, if properly employed and 
assessed, will help students to achieve the ELOs. The practices may take many different forms of implementation, depending on both the characteristics of the learners and institutional priorities and contexts. In particular:

- First-Year Experiences (FYE) -- Designed to help students prepare for the transition from high school to college, FYE programs often foster the participation of students in both academic and co-curricular events such as common readings, guest lectures, concerts, and art exhibits.

- Common Intellectual Experiences -- Common Intellectual Experiences often take the form of a unique seminar course required of all first year students and are usually designed around a common theme via which students investigate a central question.

- Learning Communities - A learning community is a group of people/students who share common academic goals and attitudes, who meet semi-regularly to collaborate on classwork. Learning communities have become the template for cohort-based, often interdisciplinary approaches to higher education.

- Writing-Intensive Courses - Writing across the curriculum (WAC) is a contemporary academic movement within the field of composition that concerns itself with writing in classes outside of composition, literature, and other English courses. Most WAC programs include a Writing to Learn (WTL) component as well as Writing in the Disciplines (WID).

- Collaborative Assignments and Projects - Team-based assignments and projects foster collaboration among students. If the teams are appropriately formed and assignments are appropriately designed, such projects can also be used to foster an appreciation of diverse backgrounds and cultures.

- Undergraduate Research - under the guidance of a faculty member, undergraduate research is the exploration of a specific topic within a field by an undergraduate student that makes an original contribution to the discipline.

- Diversity/Global Learning - Study abroad opportunities provide students with the opportunity to become a much worldlier person, thereby becoming more marketable to employers and graduate schools. By studying abroad students also gain a greater appreciation for diverse perspectives and cultures, especially so for those students who have never traveled abroad prior to college.

- Service Learning, Community-Based Learning - Service learning is an educational approach that balances formal instruction and direction with the opportunity to serve in the community, which provides for a much more pragmatic learning experience while simultaneously providing a service to others.

- Internships -- An internship provides students with the opportunity to use their academic training in a professional environment while simultaneously providing the student with career-related experience.

- Capstone Courses and Projects -- A capstone course or capstone project serves as the culminating and usually integrative experience of an educational program.

Yet these practices in and of themselves, if employed just in the general education courses, are not sufficient to provide the soft skill learning experiences that the employers of our students so strongly desire. If not reinforced throughout the major curriculum, independent of the student's major, the practices will be thought of by students as little more than applicable to the liberal arts disciplines. At Quinnipiac University we have intentionally adopted the use of HIPs in our baccalaureate CIS program as a pedagogical approach to address industry's concern with the lack of soft skills of today's undergraduates. We offer this following approach to the reader for consideration and possible adoption.

\section{USING HIGH IMPACT PRACTICES IN THE CIS CURRICULUM}

"If we want to improve the quality of undergraduate education, a million workshops on teaching will not be enough. Good teaching cannot be reduced to technique; good teaching comes from the identity and integrity of the teacher."

- Parker Palmer

A common attitude among today's undergraduate CIS majors is that they do not appreciate the value of the liberal arts distribution courses they are required to take. Without this fundamental understanding, students are prone to view liberal arts course requirements as little more than boxes to be checked off on their undergraduate course planning 
worksheets. Consequently our students will lack an appreciation of the "soft skills" that can be improved/refined by an exposure to the liberal arts. Perhaps what is needed to overcome this problem is the intentional deployment of pedagogy approaches that effectively stresses the importance of the concepts and mindsets derived from liberal arts exposure to our students. To accomplish this we have intentionally adopted the use of High Impact Practices (HIPs) where appropriate in our curriculum. In particular, the HIP's are currently in use as follows:

\section{First Year Experiences}

All first year students are enrolled in FYS 101 - First Year Seminar, specifically designed to help students examine a fundamental issue or question from multiple perspectives. This seminar is designed to accomplish three essential goals. First, it introduces students to the concept of inquiry as a process that utilizes multiple approaches and perspectives to systematically investigate questions or problems. Students learn that the process of inquiry includes the collection, analysis, and evaluation of various types of evidence. Second, the seminar enables students to understand how the process of inquiry works in practice through an investigation of a particular content area that the instructor selects from his/her area of expertise. Finally, students begin to develop a guiding question that they wish to explore throughout their undergraduate experience in light of the skills and knowledge they have acquired throughout this course.

The CIS program is located in the School of Business. All School of Business students take both SB 101 The Business Environment and SB 111 Personal Effectiveness during their first semester, as well as CIS 101 Introduction to Information Systems during either their first semester or second semester. All CIS majors are enrolled in CIS 101 during their first semester. SB 101 introduces students to the major fields of business in an integrated framework built around a competitive business simulation. In SB 111 students begin the process of developing the personal and professional skills required to succeed in college and in business. Topics covered include self-motivation, goal setting, managing time and priorities, interpersonal leadership and study skills. In CIS 101 students are introduced to contemporary information systems and how these systems are used in organizations. The focus is on the key components of information systems and how these components can be integrated and managed to create competitive advantage. This course also provides an introduction to systems and development concepts, technology acquisition, and various types of application software that have become prevalent or are emerging in modern organizations and society.

\section{Common Intellectual Experiences}

All Quinnipiac University students take a 46 credit common university core curriculum, all School of Business students take a 46 credit School of Business core, and all CIS majors take a 21 credit CIS core and a minimum of 9 credits of CIS electives. Courses are carefully sequenced to insure that all CIS majors who enter the program in a given academic year are taking the same CIS core courses at the same time, and both the university curriculum and school of business core further provide for common student intellectual experiences.

\section{Learning Communities}

A learning community is a group of people who share common academic goals/attitudes and who meet semi-regularly to collaborate on classwork. Such communities have become the standard template for a cohort-based, interdisciplinary approach to higher education. At present formal learning communities are not being employed across the university. In the school of business, cohorts are used in the first year student experiences across SB 101 and SB 111. Descriptions of both SB 101 and SB 111 were provided in the prior First Year Experiences section.

\section{Writing-Intensive Courses}

Writing-Intensive Courses are those in which writing is used both as a central mode of learning and as a means of evaluating student performance. Students write regularly, and their grades are closely linked to the quality and content of their written work. These courses usually combine both "writing-to-learn" (WTL) and "writing-in-the-disciplines" (WID) activities as central to how the subject matter is presented and how it is learned, thereby offering students a 
chance to learn about the process of writing by writing often, in different ways and for different audiences, as well as a chance to become competent communicators in a specific field of study.

Quinnipiac University CIS courses are not technically writing-intensive courses because they do not strictly adhere to all of the required components for a writing-intensive course. However, most CIS courses include a writing component, including both WTL and WID components. In particular, "writing-in-the-disciplines" activities are designed to help students write professionally acceptable documents in the CIS field of study. CIS courses also provide for emphasis on effective communication, and students are required to demonstrate a mastery of the conventions of writing in the field of CIS. Instructors devote a substantial amount of class time to the development of the specific skills required in CIS writing projects. Additionally, faculty provide extensive feedback throughout the developing stages of the writing projects, and peer feedback is strongly encouraged. (Saulnier, 2015)

\section{Collaborative Assignments and Projects}

Team-based assignments are used throughout the curriculum. In CIS 101 Introduction to Information Systems student teams develop an iPhone mockup and present their mockups to the entire class who acts as an organization steering committee. In CIS 125 Systems Analysis \& Design student teams work through the analysis, requirements definition, and design stages of the System Development Life Cycle (SDLC) to address a system problem. The problem may be either for an on campus system or for an off-campus not-for-profit entity, and the produced deliverables become the basis for the detailed development and implementation stages of the SDLC that addressed in subsequent required courses. In CIS 490 CIS Capstone student teams are required to deliver a project that may encompass project management, systems analysis and design, enterprise systems, database management systems, and programming.

\section{Undergraduate Research}

At present undergraduate research is not emphasized in the curriculum. Though occasional student-faculty research collaborations have occurred, and some of these collaborative efforts have resulted in conference presentations and/or publications, such collaborations are indeed very rare. Given the rapidly changing nature of the field, coupled with the need to cover significant content-driven information within the major credit hour restrictions of an AACSB accredited business school, it is very doubtful that the quantity of undergraduate research will improve over the foreseeable future.

\section{Diversity/Global Learning}

Emphasis on diversity in the CIS program is provided not by what we say, but by what we do. This emphasis on diversity has as least four distinct components: the composition of our faculty, the composition of our student majors, our emphasis on providing "safe spaces" and a welcoming environment to all, and our active support of study abroad opportunities.

Though small in number our department full-time faculty are intentionally a diverse group. There are four faculty who were born in the US and three faculty who were born elsewhere (Germany, India, and Morocco). Two of the seven faculty are multi-racial (Oriental-Caucasian, and African-American-Caucasian). Additionally, for the past three years we have maintain a male: female ration of $4: 3$.

The diversity of our faculty coupled with the global nature of our discipline draws a very diverse group of student majors. In terms of our undergraduate enrollment, we are significantly above the overall campus percentages for minority, foreign, and LGBTQ student majors. We are currently investigating the possibility of having our office complex designated as a "safe space", formally indicating that we do not tolerate anti-LGBT violence, harassment or hate speech, thereby creating a safe place for lesbian, gay, bisexual, and transgender students, faculty, and staff.

We strongly encourage our students to take full advantage of the university's many study abroad opportunities, and approximately $1 / 3$ of our CIS majors participate in a study abroad opportunity as part of their four year course of study. These opportunities range from semesters abroad to J-term opportunities to service learning opportunities abroad during January and/or spring breaks. 


\section{Service Learning, Community-Based Learning}

Both CIS 125 Systems Analysis \& Design and CIS 440 IT Project Management have service components as part of the class structure. Though not strictly Service Learning (SL) courses because they do not require all of the necessary components to qualify as a SL courses, both courses provide students with the opportunity to engage in community service. In CIS 125 students have designed systems that have subsequently been implemented on our campus as well as in the surrounding community, and in CIS 440 students will be designing a web site for the Pavarotti Center, a middle school located in Guatemala.

Our student organization, the Computer Information Systems Society (CISS), also has a very strong service component. Upper class students routinely provide tutoring services to students struggling in lower-level major courses, and the CISS participates in Quinnipiac University's celebration of The Big Event. Since its inception at Texas A\&M University in 1982, The Big Event has become the largest, one-day, student-run service project in the nation. Each spring, students come together across the nation to support their surrounding communities and say "Thank You" to the residents of the communities in which they are located by completing service projects such as yard work, window washing, and painting for residents of the community. Members of the CISS have worked on landscaping the grounds of the local YMCA, worked for a local firm that accepts furniture donations and turns those around to local families and individuals in need by making it easier for potential clients to see what furniture is currently available to them. Additionally, they have worked to seamline the availability and delivery processes for a local firm that provides services and/or items to pregnant women who are not in a position to obtain those items for themselves.

\section{Internships}

Over the past 40 years an internship has been a CIS program requirement for the bachelor's degree. Though initially difficult to provide sufficient number of internships for the size of our student body, as the years have passed and our program graduates have risen through the ranks of major corporations our program's reputation has grown and we now enjoy a robust reputation for program excellence. We currently find ourselves in the enviable position where we have more internship opportunities than adequately prepared students available to fill the internships, and more employment opportunities available for program graduates than graduates to meet the current demand.

\section{Capstone Courses and Projects}

Capstone courses for CIS majors at are required at both the school of business and CIS program levels. At the school of business level, the capstone course focuses on senior management responsibilities in formulating and implementing short- and long-term corporate strategy. The course integrates critical concepts from core business subjects including accounting, computer information systems, economics, finance, international business, management, marketing, and operations management. Course activities include case studies, individual and/or group projects and computerized business simulations.

In CIS 490 students employ skills learned in all other CIS courses, and student teams are required to deliver a project that may encompass project management, systems analysis and design, enterprise systems, database management systems, and programming. The teams are responsible for managing the entire project from conceptual design to final deliverables.

\section{CONCLUSIONS AND RECOMMENDATIONS}

"Reasoning draws a conclusion, but does not make the conclusion certain, unless the mind discovers it by the path of experience."

- Roger Bacon.

Direct contact with employers who have hired our program graduates has revealed that the employers are very satisfied with our graduates' soft skills. The employers have indicated that given these soft skills they can effectively teach the 


\section{Issues in Information Systems}

Volume 18, Issue 1, pp. 109-117, 2017

new hires the required technology skills particular to their company, or they can reasonably expect that the new employees can teach themselves the company-specific technology skills. Placement statistics for our program graduates are truly excellent; of the twenty-two program graduates of the class of 2015 , placement was $100 \%$ with 21 graduates currently working in the field and one graduate enrolled full-time in graduate school.

The deployment of High Impact Practices (HIPs) throughout our undergraduate curriculum has effectively moved students toward the attainment of the Essential Learning Outcomes (ELOs), which in turn has effectively served to meet the employer expectations for the "soft skills" of CIS graduates. Students have developed/improved their personal and interpersonal skills that employer place at the top of their wish-lists for new employees. In particular, the students have improved their ability to engage in individual and collective problem solving, their ability to effectively work in team environments, and their ability and comfort working in a world of "permanent white water" and adapting to new/changing technologies. These "soft skills" have been developed while they are simultaneously developing their technical expertise/skills that employers consider to be very important. Student reaction to the adoption of HIPs throughout the curriculum has been positive, and there has been no substantive change in student course evaluations since the intentional adoption of HIPs.

When focusing on CIS curricular development efforts, the use of research-based effective pedagogy has proven to be just as important as defining the content of our curriculum. Yet how many of us in higher education have studied principles of effective pedagogy? In the absence of that knowledge base across the CIS faculty, the use of the HIPs of the LEAP initiative has served as the pedagogical framework for providing our students with the ELOs necessary for the development of soft skills that employers expect of today's college graduates.

\section{REFERENCES}

Aasheim, C., Shropshire, J., Li, L., \& Kadlec, C. (2012). Knowledge and skill requirements for entry-level IT Workers: A longitudinal study. Journal of Information Systems Education, 23(2), 193-202.

Bacon, R. Retrieved April 21, 2016 from http://thinkexist.com/quotation/reasoning_draws_a_conclusionbut_does_not_make/263098.html.

Bailey, J. L. (2014). Non-technical skills for success in a technical world. International Journal of Business and Social Science, 5(4), 1-10.

Cappel, J. J. (2002). Entry-level IS job skills: A survey of employers. Journal of Computer Information Systems, 42(2), 76-82.

Cross, K.P. (1987). The Need for Classroom Research. To Improve the Academy. Stillwater, OK: POD Network in Higher Education.

Drucker, P. Retrieved April 17, 2016 from https://bloggingonthebrightside.wordpress.com/2014/04/02/the-greatestdanger-in-times-of-turbulence-is-not-the-turbulence-it-is-to-act-with-yesterdays-logic/

Gretzky, W. Retrieved April 17, 2016 from http://www.brainyquote.com/quotes/authors/b/bill_gates.html

Hart Research Associates (2013). It Takes More Than a Major: Employer Priorities for College Learning and Student Success. Washington DC: Association of American Colleges and Universities.

Heckman, J. J., \& Kautz, T. (2012). Hard evidence on soft skills. Labor Economics, 19(4), 451-464.

Janicki, T. N., Kline, D., Gowan, J. A., \& Konopaske, R. (2004). Matching employer needs with IS curriculum: An exploratory study. Information Systems Education Journal, 2(21), 3-19. 
Kuh, G. D. (2008). High-Impact Practices: What They Are, Who has Access to Them, and Why They Matter. Washington, D.C.: Association of American Colleges and Universities.

Lang, G., Jones, K. \& Leonard, L. (2015). In the Know: Desired Skills for Entry-Level Systems Analyst Positions. Issues in Information Systems, 16(1), 142-148.

LEAP (2005) Liberal Education and America's Promise. Washington, DC: Association of American Colleges and Universities.

McMurtrey, M., Downey, J., Zeltmann, S., \& Friedman, W. (2008). Critical skill sets of entry-level IT professionals: An empirical examination of perceptions from field personnel. Journal of Information Technology Education: Research, 7(1), 101-120.

Palmer, P. (1998) The Courage to Teach: Exploring the Inner Landscape of a Teacher's Life. San Francisco: JosseyBass.

Plice, R. K., \& Reinig, B. A. (2007). Aligning the information systems curriculum with the needs of industry and graduates. Journal of Computer Information Systems, 48(1), 22-30.

Schneider, C. G. (2015) The LEAP Challenge: Transforming for Students, Essential for Liberal Education. Liberal Education, $101(1 / 2)$.

Vaill, P. (1989) Managing as Performing Art: New Ideas for a World of Chaotic Change. San Francisco: JosseyBass.

Vaill, P. (1996) Learning as a Way of Being: Strategies for Survival in a World of Permanent White Water. San Francisco: Jossey-Bass.

Wilkerson, J. W. (2012). An alumni assessment of MIS related job skill importance and skill gaps. Journal of Information Systems Education, 23(1), 85-97. 